\title{
MENINGKATKAN HASIL BELAJAR MENGGUNAKAN METODE KOOPERATIF TIPE JIGSAW PADA MATERI AKHLAK TERCELA DI SMA
}

\author{
Ifa Laila \\ Guru SMA Negeri 7 Pontianak \\ Email:ifalaila70@gmail.com
}

\begin{abstract}
Abstrak
Dalam Penelitian ini terdapat 12 orang siswa yang tidak aktif berdiskusi ketika proses pembelajaran berlangsung. Atau hanya $60 \%$ siswa yang aktif berdiskusi ketika proses pembelajaran berlangsung dan Terdapat 8 orang siswa yang tidak mendengarkan penjelasan temannya. Atau hanya $73,30 \%$ siswa yang hanya mau mendengarkan penjelasan tamannya. Namun pada penerapan siklus II dengan menerapkan model pembelajaran yang sama ternyata aktivitas siswa mengalami peningkatan yang signifikan yaitu: Terdapat 26 orang siswa $86.57 \%$ siswa aktif membaca teks meteri yang diberikan. Terdapat 24 orang atau $80 \%$ siswa yang aktif berdiskusi dan telah melebihi skor ideal yaitu $75 \%$. Ada 27 orang atau $90 \%$ siswa yang aktif mendengarkan penjelasan temannya dan sangat melebih skor ideal yang ada. Menunjukan ada peningkatan hasil belajar dengan menggunakan metode kooperatif tipe Jigsaw
\end{abstract}

\section{Kata Kunci: Hasil belajar, Materi Akhlak Tercela, Model Kooperatif Tipe Jigsaw}

\section{PENDAHULUAN}

Berdasarkan pengamatan awal yang peneliti dapatkan dari laporan hasil belajar siswa kelas XI IPA1 Mata Pelajaran PAI melalui pengambilan data dari guru yang bersangkutan bahwa, dari hasil ulangan semester ganjil terdapat sebanyak 12 siswa dari 30 siswa atau $40 \%$ tidak mendapatkan nilai 70 sebagai batas nilai ketuntasan (Sumber: laporan hasil belajar siswa kelas XI IPA1 2018/2019 mata pelajaran PAI). Diduga penyebabnya adalah: 1) siswa kurang bersungguh-sungguh dalam mengikuti pembelajaran, 2) siswa tidak mau menjawab pertanyaan guru, 3) siswa tidak mau bertanya terhadap materi yang tidak atau kurang dimengerti, 4) tidak mau menyampaikan pendapatnya saat pembelajaran berlangsung. Adanya siswa yang kurang bersemangat dalam mengikuti pembelajaran disebabkan karena siswa merasa bosan terhadap situasi belajar yang tidak berubah. Pembelajaran di sekolah masih menggunakan model pembelajaran yang kurang diminati yaitu tidak menyenangkan dan terkesan cepat membosankan bagi siswa. Hal ini diperkuat oleh pendapat Bahruddin, (Kompas, 2008: 9) bahwa "apabila proses pembelajaran tidak bisa memberikan rasa nyaman maka keberhasilan anak untuk belajar kurang 50 persen" kurang berhasil meningkatkan prestasi belajar siswa.

Untuk mengatasi masalah ini tentunya harus ada upaya yang dilakukan oleh guru. Kalau harus merubah keadaan fisik kelas tentu akan merepotkan pihak sekolah. Namun ada upaya yang lebih mudah untuk dilakukan, dengan melakukan inovasi pada penggunaan metode pembelajaran. Penggunaan metode pembelajaran yang inovatif akan berpengaruh terhadap situasi pembelajaran, sehingga situasi pembelajaran tidak lagi membosankan.

Oleh karena itu, peneliti tertarik pada salah satu alternatif metode pembelajaran yang dapat diterapkan dalam Pembelajaran Agama Islam yaitu model pembelajaran kooperatif tipe jigsaw. Metode pembelajaran ini mengandung unsur pendekatan kooperatif dengan mendayagunakan semua kemampuan siswa yang heterogen. Diharapkan dengan menerapkan metode pembelajaran seperti ini guru dapat menciptakan suatu lingkungan belajar yang inovatif, sehingga dapat mengurangi rasa kebosanan siswa terhadap lingkungan belajar yang monoton.

Dalam pendekatan kooperatif siswa ditekankan agar saling bekerja sama, masing-masing siswa mengemukakan ide sesuai dengan kemampuan interpersonal. Tiap-tiap anggota kelompok menjadi "ahli" dalam subjek persoalannya, sehingga memiliki informasi penting yang dapat dikontribusikan kepada teman sekelas. Saling bekerja sama dan saling percaya sangat dibutuhkan dalam pencapaian akademis. Maka dengan demikian hasil belajar siswa juga akan meningkat.

Adapun alasan peneliti melakukan penelitian di kelas XI IPA1, karena hasil belajar pendidikan agama Islam siswa kelas XI IPA1 masih kurang optimal dibandingkan dengan hasil belajar siswa kelas-kelas lainnya. Selain itu, siswa kelas XI IPA1 memiliki semangat belajar yang kurang tinggi dibandingkan kelas-kelas lainnya. Dan penelitian ini nantinya akan difokuskan pada kelas XI IPA1. Karena berdasarkan daftar hasil belajar siswa terdapat 12 (dua belas) orang siswa yang belum mencapai kreteria ketuntasan minimal yang telah ditentukan pada mata pelajaran Pendidikan Agama Islam.

Model Pembelajaran Kooperatif Tipe Jigsaw. Menurut Muslimin Ibrahim (2000:12) pembelajaran kooperatif sebagai salah satu cara untuk menetapkan penguasaan dan pemahaman siswa terhadap materi pembelajaran, melatih kebiasaan siswa untuk mampu berfikir kritis dan objektif, mengembangkan inisiatif dan kreativitas serta tanggung jawab siswa terhadap penguasaan maupun penerapan pengetahuan yang diperolehnya melalui pelajaran yang diterimanya dan mengaktifkan siswa dalam suatu pembelajaran secara kelompok. Sedangkan menurut Thomson dan Smit (dalam Tanwey Gerson Ratumanan, 2002:52) pembelajaran kooperatif dilaksanakan oleh siswa yang bekerja sama dalam kelompok-kelompok kecil untuk mempelajari materi akademik dan keterampilan antar pribadi. Anggota-anggota kelompok bertanggung jawab tidak hanya untuk pelajaran yang diajarkan tetapi juga bertanggung jawab membantu teman dalam kelompok untuk 
meraih prestasi. Model pembelajaran kooperatif membantu siswa dalam memecahkan berbagai masalah yang ditemuinya selama pembelajaran. Hal ini karena siswa dapat bekerja sama dengan siswa lain dalam menemukan dan merumuskan alternatif pemecahan masalah materi pelajaran. Siswa yang kurang berminat menjadi lebih bergairah dalam belajar. Keberhasilan siswa dalam belajar bukan semata-mata harus diperoleh dari guru, tetapi dapat juga dari pihak lain yang terlibat dalam pembelajaran itu, yaitu teman sebaya.

Berdasarkan beberapa pengertian di atas, dapatlah difahami bahwa pembelajaran kooperatif adalah merupakan salah satu model pembelajaran yang dilakukan dengan cara mengelompokkan siswa dalam beberapa kelompok yang bersifat heterogen, dan mendorong siswa agar lebih aktif serta memiliki rasa tanggung jawab baik individu maupun kelompok dengan tujuan untuk mencapai tujuan pembelajaran sesuai dengan yang diinginkan.

Jigsaw dikembangkan oleh Elliot Aronson dan kawan-kawannya dari Universitas Texas dan kemudian diadopsi oleh Slavin dan kawan-kawan di Universitas John Hopkins (Trianto, 2009:73). Menurut Arends dalam Sharan (2009:45) pengertian pembelajaran jigsaw adalah: “...salah satu model pembelajaran kooperatif yang terdiri dari tim-tim belajar heterogen beranggotakan 4 sampai 6 orang siswa. Materi akademik disajikan dalam bentuk teks dan setiap siswa bertanggung jawab atas penugasan bagian materi belajar dan mampu mengajarkan bagian materi tersebut kepada anggota tim lain".

Menurut Mell Silbermen dalam Komaruddin Hidayat (2002:160) bahwa: "Jigsaw merupakan teknik yang dipakai secara luas yang memiliki kesamaan dengan teknik "group to group exchange" (pertukaran dari kelompok ke kelompok) dengan suatu perbedaan penting yaitu setiap peserta didik mengajarkan sesuatu". Lebih lugas Shlomo Sharan (2009:49) mengatakan: "Dalam pendekatan ini, siswa bekerja sama dalam kelompok-kelompok kecil dan mereka harus saling membantu. Tiap-tiap anggota kelompok menjadi "ahli" dalam subjek persoalannya, sehingga memiliki informasi penting yang dapat dikontribusikan kepada teman sekelas".

Dari beberapa defenisi di atas, dapatlah disimpulkan bahwa jigsaw adalah teknik pembelajaran kooperatif di mana siswa, bukan guru, yang memiliki tanggung jawab lebih besar dan lebih proaktif dalam melaksanakan pembelajaran dengan tujuan untuk mengembangkan kerja tim, keterampilan belajar kooperatif, dan menguasai pengetahuan secara mendalam terhadap materi yang telah diberikan dengan cara mereka mencoba untuk mempelajari semua materi sendirian yang kemudian mereka akan mengajarkannya kepada yang lain.

Hasil Belajar. Berdasarkan pendapat di atas, dapatlah disimpulkan bahwa hasil merupakan suatu (akibat) yang telah dilakukan seseorang melalui kegiatan tertentu. Yang dalam hal ini berkaitan dengan kegiatan yang dilakukan oleh seseorang (pelajar) yaitu belajar materi Pendidikan Agama Islam (PAI) di sekolah, khususnya di SMA Negeri 7 Pontianak.

Sedangkan pengertian belajar sebagaimana yang diungkapkan oleh Sardiman (2005:21) adalah: "Sebagai rangkaian kegiatan jiwa raga, psikofisik untuk menuju perkembangan pribadi manusia seutuhnya, yang berarti menyangkut unsur cipta, rasa dan karsa, ranah kognitif, afektif dan psikomotorik". Lebih lanjut Slameto (1995:2) menyatakan, bahwa: "Belajar adalah proses usaha yang dilakukan individu guna memperoleh suatu perubahan tingkah laku secara keseluruhan sebagai hasil pengalaman individu itu sendiri dalam interaksi dengan lingkungannya" sebuah bentuk inkuiri reflektif yang dilakukan secara kemitraan mengenai situasi sosial tertentu (termasuk pendidikan) untuk meningkatkan rasionalitas dan keadilan dari a) Kegiatan praktek sosial atau pendidikan mereka, b) pemahaman mereka mengenai kegiatan-kegiatan praktek pendidikan ini, dan c) situasi yang memungkinkan terlaksananya kegiatan praktek ini.

\section{METODE PENELITIAN}

Penelitian ini menggunakan metode penelitian tindakan kelas. Menurut Kammis (dalam Wiriaatmadja, 2009:12) meningkatkan penelitian tindakan adalah

Sedangkan Menurut Kunandar (dalam Iskandar, 2009:21) mengatakan bahwa: "Penelitian Tindakan Kelas (PTK) adalah suatu kegiatan yang dilakukan oleh seorang guru atau bersama-sama dengan orang lain (kolaborasi) yang bertujuan untuk memperbaiki/ meningkatkan mutu proses pembelajaran dikelasnya". Kemudian Susilo menambahkan:" dalam PTK, guru dapat melakukan penelitian sendiri terhadap proses pembelajaran di kelas atau juga bekerja sama dengan guru atau peneliti lain (Susilo, 2009: 16).

\section{HASIL PENELITIAN DAN PEMBAHASAN}

Pengamatan yang dilakukan terhadap: aktivitas siswa dalam proses pembelajaran kooperatif tipe jigsaw dan hasil belajar siswa.

Tabel 1. Skor Hasil Belajar Siswa pada Siklus I

\begin{tabular}{ccccc}
\hline \multirow{2}{*}{ No } & Nama Siswa & Skor Nilai & \multicolumn{2}{c}{ Keterangan } \\
\cline { 3 - 5 } & & & Tuntas & Tidak tuntas \\
\hline 1 & S01 & 60 & & Tidak tuntas \\
\hline 2 & S02 & 70 & Tuntas & \\
\hline 3 & S03 & 75 & Tuntas & \\
\hline 4 & S04 & 70 & Tuntas & Tidak tuntas \\
\hline 5 & S05 & 50 & & \\
\hline 6 & S06 & 70 & Tuntas & \\
\hline 7 & S07 & 80 & Tuntas & Tidak tuntas \\
\hline 8 & S08 & 80 & Tuntas & \\
\hline 9 & S09 & 50 & & Tidak tuntas \\
\hline 10 & S10 & 70 & Tuntas & \\
\hline 11 & S11 & 50 & & \\
\hline
\end{tabular}




\begin{tabular}{|c|c|c|c|c|}
\hline 12 & S12 & 90 & Tuntas & \\
\hline 13 & S13 & 75 & Tuntas & \\
\hline 14 & S14 & 50 & & Tidak tuntas \\
\hline 15 & S15 & 90 & Tuntas & \\
\hline 16 & S16 & 60 & & Tidak tuntas \\
\hline 17 & S17 & 80 & Tuntas & \\
\hline 18 & S18 & 70 & Tuntas & \\
\hline 19 & S19 & 75 & Tuntas & \\
\hline 20 & S20 & 50 & & Tidak tuntas \\
\hline 21 & S21 & 90 & Tuntas & \\
\hline 22 & S22 & 80 & Tuntas & \\
\hline 23 & S23 & 50 & & Tidak tuntas \\
\hline 24 & S24 & 100 & Tuntas & \\
\hline 25 & S25 & 50 & & Tidak tuntas \\
\hline 26 & S26 & 70 & Tuntas & \\
\hline 27 & S27 & 75 & Tuntas & \\
\hline 28 & S28 & 70 & Tuntas & \\
\hline 29 & S29 & 50 & & Tidak tuntas \\
\hline 30 & S30 & 60 & & Tidak tuntas \\
\hline & Jumlah & 2060 & 21 & 11 \\
\hline & Rata-Rata & 68.70 & $70 \%$ & $30 \%$ \\
\hline
\end{tabular}

Berdasarkan paparan data dari tabel skor hasil belajar siswa siklus pertama (tabel IV.3) di atas, mengindikasikan bahwa penguasaan peserta didik terhadap materi pelajaran masih tergolong kurang. Hal ini bisa dilihat dari penjelasan tebel sebagai berikut: Dari 30 orang siswa yang mengikuti proses pembelajaran pada siklus pertama hanya 21 orang siswa yang memperolah nilai tuntas sesuai KKM yaitu 70. Hal ini berarti perolahan skor siswa yang tuntas hanya $70 \%$ dan belum mencapai kategori yang ideal yaitu $75 \%$.

Dari hasil observasi terhadap aktivitas guru melaksanakan model pembelajaran kooperatif tipe jigsaw dalam kelompok, yang ditampilkan siswa dan perolehan hasil belajar dilakukan refleksi terhadap hasil temuan maupun masalah-masalah yang dirasakan selama pelaksanaan siklus I. Adapun hasil refleksi siklus I dapat dipaparkan sebagai berikut: (1) Guru belum terbiasa menciptakan suasana pembelajaran yang mengarahkan kepada pendekatan pembelajaran kooperatif tipe jigsaw.
Hal ini dapat dilihat dari lembar observasi guru yang masih belum melaksanakan langkah-langkah pembelajaran secara sempurna; (2) Sebagian siswa belum terbiasa dengan kondisi belajar dengan menggunakan model pembelajaran kooperatif tipe jigsaw. Hal ini bisa dilihat dari hasil observasi aktivitas siswa yang masih banyak tidak membaca teks yang diberikan, tidak aktif dalam berdiskusi dan tidak mau mendengarkan penjelasan teman sekelompoknya; (3) Hasil evaluasi siklus pertama hanya $70 \%$ siswa yang memperoleh nilai sesuai atau melebihi KKM yang telah ditetapkan. Hal ini tentu belum mencapai kategori keberhasilan indikator yang ditetapkan yaitu 75; (4) Masih ada kelompok yang belum mampu mempresentasikan kegiatan.

Dari hasil refleksi ini kemudian dijadikan bahan acuan untuk menyusun dan merencanakan tindakan pada siklus II. Hasil observasi aktivitas guru dalam proses pembelajaran pada siklus kedua dapat dilihat pada tabel sebagai berikut:

Tabel 2. Skor Hasil Belajar Siswa pada Siklus II

\begin{tabular}{ccclc}
\hline No & Nama Siswa & Skor Nilai & Keterangan & \\
\hline & & & Tuntas & Tidak tuntas \\
\hline 1 & S01 & 60 & & Tidak tuntas \\
\hline 2 & S02 & 90 & Tuntas & \\
\hline 3 & S03 & 90 & Tuntas & \\
\hline 4 & S04 & 6.5 & & Tidak tuntas \\
\hline 5 & S05 & 70 & Tuntas & \\
\hline 6 & S06 & 80 & Tuntas & \\
\hline 7 & S07 & 90 & Tuntas & \\
\hline 8 & S08 & 90 & Tuntas & \\
\hline 9 & S09 & 80 & Tuntas & \\
\hline 10 & S10 & 80 & Tuntas & \\
\hline 11 & S11 & 70 & Tuntas & \\
\hline 12 & S12 & 100 & Tuntas & \\
\hline 13 & S13 & 80 & Tuntas & \\
\hline 14 & S14 & 70 & Tuntas & \\
\hline 15 & S15 & 100 & Tuntas & \\
\hline 16 & S16 & 70 & Tuntas & \\
\hline 17 & S17 & 80 & Tuntas & \\
\hline
\end{tabular}




\begin{tabular}{|c|c|c|c|c|}
\hline 18 & S18 & 90 & Tuntas & \\
\hline 19 & S19 & 70 & Tuntas & \\
\hline 20 & S20 & 80 & Tuntas & \\
\hline 21 & S21 & 90 & Tuntas & \\
\hline 22 & S22 & 80 & Tuntas & \\
\hline 23 & S23 & 80 & Tuntas & \\
\hline 24 & S24 & 100 & Tuntas & \\
\hline 25 & S25 & 60 & & Tidak tuntas \\
\hline 26 & S26 & 80 & Tuntas & \\
\hline 27 & S27 & 90 & Tuntas & \\
\hline 28 & S28 & 80 & Tuntas & \\
\hline 29 & S29 & 60 & & Tidak tuntas \\
\hline \multirow[t]{3}{*}{30} & S30 & 70 & Tuntas & \\
\hline & Jumlah & 2395 & 26 & 4 \\
\hline & Rata-Rata & 7.98 & $86.67 \%$ & $13.33 \%$ \\
\hline
\end{tabular}

Dari tabel di atas, dapat diketahui bahwa hasil evaluasi yang dilakukan pada siklus II mengalami peningkatan yang signifikan daripada siklus I. Pada penerapan siklus I ratarata skor hasil evaluasi belajar siswa hanya hanya $66.67 \%$ siswa yang memperoleh nilai yang tuntas. Sedangkan pada penerapan siklus II rata-rata skor hasil evaluasi belajar siswa terdapat $86.67 \%$ siswa yang memperolah nilai yang tuntas sesuai KKM yang ada. Hal ini mengindikasikan bahwa hasil evaluasi pada siklus II mengalami peningkatan yang signifikan dan telah melebihi skor ideal yang telah ditentukan dalam indikator penelitian yaitu $75 \%$.

Adapun keberhasilan yang diperoleh selama siklus II adalah sebagai berikut: (1) Aktivitas siswa dalam proses pembelajaran sudah mengarah ke pembelajaran kooperatif tipe jigsaw. Hal ini tergambar dalam (a) siswa mampu membangun kerja sama dalam memahami tugas yang diberikan oleh guru; (b) siswa mulai mampu berpartisipasi dalam kegiatan dan tepat waktu dalam pelaksanaannya; (c) siswa mulai mampu mempresentasikan hasil kerjanya dengan baik; (2) Meningkatnya aktivitas siswa dalam proses pembelajaran didukung oleh meningkatnya aktivitas guru dalam mempertahankan dan meningkatkan suasana pembelajaran kooperatif tipe jigsaw. Guru intensif membimbing siswa dalam bekerja kelompok terutama membimbing siswa yang mengalami kesulitan dalam pembelajaran. Hal ini dapat dilihat dari tabel observasi aktivitas guru yang telah melaksanakan langkah-langkah pembelajaran secara sempurna. Meningkatnya aktivitas siswa dalam proses pembelajaran juga berimplikasi pada meningkatnya pemahaman siswa terhadap materi yang diberikan. Hal ini dapat dilihat dari hasil evaluasi yang diberikan pada setiap akhir pembelajaran. Yang mana pada siklus pertama rata-rata skor dari hasil evaluasi akhir hanya mencapai $66.67 \%$ siswa yang memperoleh nilai sesuai KKM. sedangkan pada siklus II hasil evaluasi akhir mencapai $86.67 \%$ siswa yang mempu memperoleh nilai sesuai KKM.I

\section{SIMPULAN DAN SARAN \\ Simpulan}

Hasil belajar siswa yang menggunakan model pembelajaran kooperatif, setelah diberikan tindakan pembelajaran siklus pertama (siklus I) rata-rata skor hasil evaluasi belajar siswa $66.67 \%$ dan tergolong masih dibawah skor ideal yang ada yaitu $75 \%$. Sedangkan pada penerapan siklus II skor yang terdapat $86.67 \%$ siswa yang memproleh nilai yang mencapai KKM dari hasil evaluasi akhir yang diberikan. Dengan demikian, hasil belajar dengan

\section{Saran}

Dalam upaya memperbaiki kualitas pembelajaran dan hasil belajar siswa pada mata pelajaran PAI di kelas XI IPA1 SMA Negeri 7 Pontianak, maka ada beberapa saran yang dapat disampaikan sebagai berikut: (1) Model pembelajaran kooperatif tipe jigsaw merupakan salah satu alternatif yang layak dikembangkan untuk mengatasi masalah rendahnya nilai hasil belajar siswa. (2) Karena model pembelajaran ini sangat bermanfaat khususnya guru dan siswa dalam proses pembelajaran. Maka diharapkan model pembelajran kooperatif tipe jigsaw ini dapat dilakukan dan diterapkan secara berkesinambungan. (3) Dalam kegiatan pembelajaran, hendaknya guru meningkatkan kemampuannya dan lebih kreatif dalam menerapkan metode-metode pembelajaran. (4) Kepala sekolah dan rekan-rekan guru merupakan faktor yang terkait langsung dengan penelitian tindakan kelas. Oleh karena itu, tugas kepala sekolah dan rekan-rekan guru sebagai mitra dapat mengembangkan dan mengevaluasi kemampuan guru dalam pembelajaran lebih lanjut sehingga sangat menentukan daya kreatif dan inovatif guru. Terutama dalam penerapan metode pembelajaran.

\section{DAFTAR RUJUKAN}

Barlow. 1985. Educational Psychology: The Teaching Learning Process, Chicagi the Moody Bible IOnstitute.

Ibrahim, Muslimin. 2000. Pembelajaran Kooperatif. Surabaya: University Press. 
John W. Santrock. 2009. (Terjemah: Diana Anglika), Educational Psychology, (Psikologi Pendidikan) Salema Humanika, Yogyakarta-Jakarta ,

Muhibbin Syah. 2008. Psikologi Pendidikan dengan Pendekatan Baru, Bandung: PT Remaja Rosdakarya.

Sardiman. 2005. Interaksi dan Motivasi Belajar Mengajar. Jakarta: PT Radja Grafindo.
Slameto.1995. Belajar dan Faktor-Faktor yang Mempengaruhinya. Jakarta: Rieneka Cipta.

Tim Penyusunan Modul Orentasi Perkambangan" Psikologi Pendidikan". Jakarta: Proyek Pembibitan Calon Tenagan Pen didik

Witherington HC. 1978. Educational Psychology. Terjemahan oleh M. Buchari. Jakarta: Aksara Baru 